\title{
$-0$ \\ Compensation of Regional Unemployment in Housing Markets
}

\author{
Wouter Vermeulen ${ }^{1,2}$ \\ Jos van Ommeren²
}

' CPB Netherlands Bureau for Economic Policy Analysis, The Hague,

2 Department of Spatial Economics, Faculty of Economics and Business Administration, Vrije Universiteit Amsterdam. 


\section{Tinbergen Institute}

The Tinbergen Institute is the institute for economic research of the Erasmus Universiteit Rotterdam, Universiteit van Amsterdam, and Vrije Universiteit Amsterdam.

Tinbergen Institute Amsterdam

Roetersstraat 31

1018 WB Amsterdam

The Netherlands

Tel.: $\quad+31(0) 205513500$

Fax: $\quad+31(0) 205513555$

Tinbergen Institute Rotterdam

Burg. Oudlaan 50

3062 PA Rotterdam

The Netherlands

Tel.: $\quad+31(0) 104088900$

Fax: $\quad+31(0) 104089031$

Please send questions and/or remarks of nonscientific nature to driessen@tinbergen.nl.

Most TI discussion papers can be downloaded at http://www.tinbergen.nl. 


\title{
Compensation of regional unemployment in housing markets
}

\author{
Wouter Vermeulen*), ${ }^{* *}$ ) \\ w.vermeulen@cpb.nl \\ and \\ Jos van Ommeren**) \\ jommeren@feweb.vu.nl
}

September 2005

*): CPB Netherlands Bureau for Economic Policy Analysis P.O. Box 80510, 2508 GM, The Hague

**): Free University Amsterdam, Department of Spatial Economics

De Boelelaan 1105, $1081 \mathrm{HV}$, Amsterdam

We would like to thank Pieter Gautier, Pierre Koning, Alan Manning and Piet Rietveld, who commented on early drafts of this paper, as well as participants of the EALE / SOLE World Conference 2005 in San Francisco. Discussions with colleagues at CPB and Free University Amsterdam were also most helpful. 


\title{
Compensation of regional unemployment in housing markets
}

\begin{abstract}
Why are regional unemployment differentials in Europe so persistent if, as the wage curve literature demonstrates, there is no compensation in labour markets? We hypothesize that workers in high-unemployment regions are compensated in housing markets. Modelling regional unemployment differentials as a consequence of centralized wage bargaining, we show that clearing of land markets may undo the incentive for workers to migrate to low-unemployment regions in general equilibrium. The compensating differentials hypothesis is tested on city-level data for several countries. Controlling for variation in income and amenities, housing is found to be about 3 percent less expensive on average in cities where unemployment is 10 percent up. An analysis of housing demand survey data, which takes account of housing heterogeneity, yields a similar negative relationship. The magnitude of the income effect generated by this compensating differential is consistent with a -0.10 wage curve elasticity. These findings weaken the case for regional support programs.
\end{abstract}

Keywords: regional unemployment, housing markets, wage curve, compensating differentials, hedonic models, regional policy

Classification-JEL: R23, R13, J64 
The puzzle that inspired our research is the coexistence of a wage curve and persistent regional unemployment differentials. Blanchflower and Oswald (1994) present evidence of a wage curve for a variety of countries and time periods, consistently finding wages to be 1 percent lower in regions where unemployment is 10 percent up (cf. Groot et al., 1992, Card, 1995, Baltagi and Blien, 1998). Their analysis contradicts a long-held belief that wages compensate for regional unemployment differentials, which originates from Harris and Todaro (1970) and Hall (1970, 1972). If workers in high-unemployment regions earn lower wages, one would expect regional differences in unemployment to disappear through labour migration in a relatively short period of time. However, it is well established that regional unemployment differentials may be large and very persistent, predominantly in European countries (cf. OECD, 2000, 2005, Overman and Puga, 2002).

Persistence of regional unemployment differentials is usually explained with barriers to interregional migration, possibly related to housing market institutions (cf. OECD, 2005). ${ }^{1}$ However, if regional unemployment differentials persist for a longer period, say 10 to 20 years, costly adjustment alone does not seem to be a satisfactory explanation. ${ }^{2}$ An alternative view is that these regional differences in unemployment reflect an equilibrium outcome. Workers should then enjoy the same utility in each region, being compensated in other markets for high regional unemployment rates. This second line of reasoning, the existence of compensating differentials, will be pursued in the present paper.

Although compensating differentials may operate through any consumption good a priori, the two most obvious channels are amenities and housing markets. For the United States, empirical evidence seems to support the hypothesis that workers accept less favourable labour market conditions if a region offers consumer amenities such as an agreeable climate (cf. Roback, 1982, Marston, 1985, Blomquist et al., 1988, Gyourko and Tracy, 1989, 1991). ${ }^{3}$ One may wonder however, what amenity could explain the large regional differences in unemployment, observed in for example Germany or the United Kingdom, which seem relatively homogeneous in terms of climate and natural scenery. More fundamentally, as

\footnotetext{
${ }^{1}$ The relationship between housing market institutions and migration has been investigated amongst others by Minford et al. (1987) and Hughes and McCormick (1987), who point to the lack of private sector rental units as a major factor. A related issue that has received considerable attention in the literature is the Oswald hypothesis, which states that owner occupancy raises aggregate unemployment because it hampers labour mobility (Oswald, 1999).

${ }^{2}$ For one reason, trade and mobility of capital may be expected to equilibrate regional labour market disparities over such a long period, even if labour is completely immobile.
} 
pointed out by Roback (1982), consumer amenities are capitalized in labour markets only to the extent that producers compete with consumers for land. Otherwise, they are capitalized in land markets. Therefore, it seems implausible that regional unemployment differentials within European countries are fully compensated by amenities. Carlson (2000) is the only study we are aware of that tests the amenity model on European data (for Norway), and he rejects it. The alternative hypothesis that workers are compensated in land (housing) markets has received less attention in the literature so far. ${ }^{4}$ This is all the more surprising, because in many countries, the observation that houses are less expensive in high-unemployment regions seems almost evident.

Although we believe that compensation in housing markets may occur in several institutional settings, we will present here a stylized core-periphery model with centralized wage bargaining. In many continental European countries, centralized wage bargaining covers more than 80 percent of employees (OECD, 2004), so it seems a natural starting point for explaining regional unemployment. ${ }^{5}$ In our model, this labour market distortion hampers adjustment of wages to lower labour productivity levels in the periphery, which results in unemployment. We demonstrate that in general equilibrium, workers in the periphery are compensated by lower house prices.

Compensation in housing markets may be relevant not only in equilibrium, but also in the adjustment process towards equilibrium. Durability and inelastic supply of housing, possibly related to growth controls or other spatial policies, imply a strong relationship between prices and labour market shocks (cf. Glaeser and Gyourko, 2005, Glaeser et al.,

\footnotetext{
${ }^{3}$ Most of these papers consider compensation for wage differentials, rather than unemployment.

${ }^{4}$ Compensation in housing markets has received some attention in the urban economics literature. For example, Zenou and Smith (1995) and Brueckner and Zenou (1999) present urban efficiency wage models, in which there is a trade off between local unemployment and house prices. Smith and Zenou (2003) present a model with compensation in housing markets where the labour market imperfection is mismatch rather than costly monitoring. At the level of regions, the existence of compensating differentials is indicated indirectly by the limited sensitivity of aggregate migration to regional wage and unemployment differentials, found in numerous studies (cf. OECD, 2000, 2005). Analyses that include regional house prices tend to find that they affect migration patterns significantly (cf. Jackman and Savouri, 1992, Cameron and Muellbauer, 1998). These results are consistent with the view that lower house prices compensate workers for less favourable regional labour market perspectives. Finally, we refer to two papers that evaluate the impact of regional house prices on earnings and unemployment in the UK (Blackaby and Manning, 1992, and Cameron and Muellbauer, 2001). These studies find upward effects of house prices on earnings, which is consistent with compensation of wages in housing markets. Cameron and Muellbauer (2001) also find an upward effect of house prices on unemployment, which they interpret as an (exogenous) cost-of-location effect. Modelling earnings and unemployment, these studies do not provide direct evidence of compensation in housing markets.

${ }^{5}$ However, there have been hardly any attempts to analyse these consequences in a formal economic model. An exception is Faini (1999), who relates unionization of unskilled workers to depressed growth in backward regions. The author provides two interesting cases that highlight the impact of centralized wage bargaining. He relates the surge in unemployment in East Germany in the period 1990 - 1992 to a decrease in wage inequality
} 
2005). For example, as migrants move away from regions experiencing adverse demand shocks, house prices may increase in low unemployment regions (inelastic short-run supply) and decrease in high unemployment regions (durability). The resulting compensating differential may be larger than capitalization in land markets can account for.

The empirical evidence presented in this paper is based on two types of data. Information on labour and housing market conditions at the city level is derived from the Urban Audit (European Commission, 2004). Negative bivariate relationships between average house prices per square meter and unemployment rates are established for all 9 European countries in our sample. Elasticities in a range from -0.4 to -0.6 cannot be rejected at the 10 percent level of significance for any country. Controlling for income and amenity differentials, an elasticity to unemployment of about -0.3 is found.

Estimates based on the city-level data may overstate the compensating differential, if households in low-unemployment cities occupy houses that are of a higher quality, or understate it, if these houses are smaller on average. ${ }^{6}$ These objections are examined in an analysis that employs housing demand survey data for the Netherlands. We obtain regional land rent differentials by regressing house prices on characteristics and region dummies. For both house prices and land rents, a negative elasticity is found in the same order of magnitude as indicated by the European data.

We embed the compensating differentials hypothesis in a theoretical framework in the next two sections. The general equilibrium model with centralized wage bargaining will be presented in Section 2, whereas the role of housing markets in regional adjustment processes is the subject of section 3. Section 4 contains our empirical analyses, both of city-level and micro data. In concluding the paper, Section 5 interprets the magnitude of the compensating differential implied. Furthermore, we discuss a number of policy implications here. The most fundamental one probably is that evidence of compensation weakens the case for regional support programs, of which there is an abundance in the European Union and many of its member states nowadays.

and he notes that unemployment in the Italian Mezzogiorno region rose rapidly after the 1968 push for wage equalization. Overman and Puga (2002) also provide a stylized model with regional wage rigidities.

${ }^{6}$ The housing markets literature stresses that (extreme) heterogeneity is a fundamental property of housing as a consumption good (Smith et al., 1988). 
In a long-run equilibrium, land prices are likely to be the main determinant of regional house price differentials. Hence, we model regional land markets rather than housing markets in this section. The essential property of land that generates compensating differentials is that it is neither tradable nor producible. Intuitively, land prices are higher in regions with attractive labour market conditions, because more workers want to live there, and supply is fixed. ${ }^{7} \mathrm{We}$ formalize this intuition in a general equilibrium model in which the labour market is characterized by centralized wage bargaining. ${ }^{8}$ Wage setting in this model is dominated by the economic conditions in the core region, in which labour is more productive than in the periphery. Unemployment in peripheral regions results because wages, set at the national level, exceed the marginal productivity of labour. In equilibrium, clearing of land markets undoes the incentive for workers to move to the core.

\section{Regional land markets}

The regional supply of land is assumed to be fixed in our model. Hence, a market clearing rent can be derived by solving the consumer problem, under the additional assumption that firms do not use land as a production factor. Suppose that all workers are homogeneous, consuming land $S$ and a composite good $X$. Given a Cobb-Douglas functional form, the utility equals $U\left(X_{i}, S_{i}\right)=S_{i}^{\beta} X_{i}^{1-\beta}$, where subscript $i$ denotes the region. Dependent on the workers' employment status, her income $I_{i}$ equals the regional wage $w_{i}$ or unemployment benefits $b$ (with $\left.b<w_{i}\right){ }^{9}$ It is assumed that the composite good is traded on world markets, and its price is normalized to unity. The land rent $r_{i}$ faced by a worker is specific to the region of residence. Solving the utility maximization problem, the worker consumes $(1-\beta) I_{i}$ units of $X$ and $\beta I_{i} / r_{i}$ units of land.

For simplicity, we assume that each region has the same endowment of land, which is normalized to unity. Let $P_{i}$ denote the regional population. Furthermore, $u_{i}$ is the

\footnotetext{
${ }^{7}$ A positive relationship between the size of the regional workforce and land prices may work through a more subtle channel than fixed supply of land. Suppose that in each region, workers live in a city and provide labour in the local Central Business District. It is well established in the urban economics literature that the costs of living in a city increase with city size, either through commuting costs or land prices (cf. Fujita, 1989). Therefore, as more workers move to the core city to earn higher wages, the costs of living increase. In equilibrium, wage differentials are fully compensated by the sum of house prices and commuting costs in such a model.

${ }^{8}$ Alternatively, we could have chosen labour market frictions or efficiency wages as a source of regional unemployment differentials, to arrive at similar results. For example, Blanchflower and Oswald (1994) present a regional efficiency wage model that can be easily extended with land markets.

${ }^{9}$ The worker is assumed to consume land and supply labour in the same region, so there is no commuting.
} 
(endogenous) regional unemployment rate. Clearing of land markets implies the following equilibrium rent:

$r_{i}=P_{i} \beta\left[u_{i} b+\left(1-u_{i}\right) w_{i}\right]$

The rent equation (1) illustrates an important mechanism. In the first place, incomes are partly capitalized in land markets, and secondly, rents increase with the regional population. Therefore, rents decrease with the regional unemployment rate, because the average income is lower in a high-unemployment region, and because such a region will attract less inhabitants in equilibrium $\left(\partial P_{i} / \partial u_{i}<0\right)$.

\section{Labour markets and centralized wage bargaining}

Regional differences in labour productivity drive regional unemployment differentials. Economies of agglomeration are a plausible source of productivity differentials, but as the focus of this paper is on interaction of labour and land markets, we do not take up the burden of modelling these explicitly. ${ }^{10}$ Instead, we assume that regions have different endowments of capital, and therefore vary in productivity. Capital is not traded between regions. As we will analyse a core-periphery model, we assume that the core has a larger endowment of capital. Each region specializes in the production of a different good that is traded on world markets.

Let $C_{i}$ denote the endowment of capital in region $i$. Suppose that region 1 is the core, and region 2 is the periphery, then $C_{1}>C_{2}$. For simplicity, we assume that elasticities of substitution between labour and capital are the same in each region. Labour and capital are the only inputs in the production process, so input markets for intermediate goods as well as land are ignored. Under Cobb-Douglas technology, production equals $Q_{i}=L_{i}^{\alpha} C_{i}^{1-\alpha}$, where $L_{i}$ denotes labour. Equating marginal costs to marginal productivity and normalizing output prices to unity, we obtain the factor demands $L_{i}=\alpha Q_{i} / w_{i}$ and $C_{i}=(1-\alpha) Q_{i} / s_{i}$, where $s_{i}$ denotes the rent to capital. We substitute the demand for labour in the production function to obtain $Q_{i}=\alpha^{\alpha / 1-\alpha} w_{i}^{-\alpha / 1-\alpha} C_{i}$. In turn, substitution of $Q_{i}$ in the labour demand equation yields $L_{i}=\alpha^{1 / 1-\alpha} w_{i}^{-1 / 1-\alpha} C_{i}$. The level of production and labour demand are thus determined by the wage and the regional endowment of capital.

\footnotetext{
${ }^{10}$ See Helpman (1998), Tabuchi (1998) or Ottaviano et al. (2002) for models with endogenous agglomeration economies, where urban cost of living differentials are a source of dispersion. However, these models do not consider labour market imperfections and unemployment.
} 
An important element of our model is that, instead of clearing labour markets in each region, wages are set at the national level $\left(\right.$ so $\left.w_{l}=w_{2}\right)$. Although several union strategies can be modelled in our framework, we make the simplifying assumption that the core is dominant in wage negotiations. Therefore, wages are set such that markets clear in the core region. As labour is less productive in the periphery, the wage is set above market clearing level in this region. Assuming that every worker supplies one unit of labour, equating labour demand and supply in the core (region 1) yields $w=\alpha\left(C_{1} / P_{1}\right)^{1-\alpha}$. Substituting this wage in the labour demand equation for the periphery (region 2), we obtain $L_{2}=P_{1} C_{2} / C_{1}$. As long as $P_{1}$ is such that labour demand in the periphery does not exceed supply, the unemployment rate in this region can then be computed:

$u_{2}=1-\frac{P_{1}}{P_{2}} \frac{C_{2}}{C_{1}}$

It will be shown that in an interregional equilibrium, the population in region 2 does exceed labour demand.

\section{Interregional equilibrium}

The condition for interregional equilibrium is that expected utility in each region is equal. Each worker in a region faces the same probability of becoming unemployed, and workers choose a region knowing this probability in advance. When choosing their region of residence, workers do not face any migration costs, but these costs are prohibitively high afterwards. In other words, workers choose a region of residence for their life time. We thus rule out situations in which workers enjoy low land prices in the periphery, but move to the core immediately after they have become unemployed. ${ }^{11}$

Substituting demand for land and the composite good in the utility function and equating expected indirect utility in each region, we obtain the equilibrium condition:

$r_{1}^{-\beta} w=r_{2}^{-\beta}\left[b+\left(1-u_{2}\right)(w-b)\right]$

\footnotetext{
${ }^{11}$ Compare for example the regional efficiency wage model in Blanchflower and Oswald (1994), where a similar assumption is made.
} 
In order to arrive at a simple analytical solution, we assume that the benefit level is zero. Substituting the rent equation (1) and the unemployment equation (2) into the equilibrium condition (3) yields after some rewriting $P_{1} / P_{2}=\left(C_{1} / C_{2}\right)^{1-\beta}$. The majority of people live in the core, where the capital endowment is largest and labour market conditions are the most favourable. The implied unemployment rate is $u_{2}=1-\left(C_{2} / C_{1}\right)^{\beta}$. We verify that labour supply in the periphery exceeds demand as $C_{1}>C_{2}$. The rent gradient can be expressed in terms of the peripheral unemployment rate in the following way:

$$
\frac{r_{2}}{r_{1}}=\left(1-u_{2}\right)^{1 / \beta}
$$

Equation 4 shows that regional land rent differentials correlate negatively to unemployment differentials, compensating workers for less favourable labour market conditions. It provides an economic interpretation for estimates of the relationship between house prices and unemployment, which will be presented in a more general framework in Section 4. ${ }^{12}$

Finally, note that the condition that wages are the same in each region may be relaxed. For instance, let us assume that regional wage rigidities due to bargaining at the national level hamper full adjustment to local labour market conditions, without restricting the wage at exactly the same level in each region. Unemployment exists in the periphery as long as the wage is set above its competitive level, and regional wages and unemployment correlate negatively. Hence, in this extension, both a wage curve and regional unemployment differentials are observed in equilibrium.

\section{Compensation and regional adjustment}

Housing markets may play a major role not only in a long-run compensating equilibrium, but also in the adjustment process towards such an equilibrium. Relevant properties of housing markets that generate compensation are inelastic supply and durability of constructs. Even in the absence of any government involvement in housing or related input markets, short-run supply of housing is inelastic because of the construction process. Making land suitable for

\footnotetext{
${ }^{12}$ In order to close the general equilibrium model, we have to discuss ownership of land and capital. Suppose that land and capital are owned by a government, which leases these commodities to consumers and producers respectively. The rents are used to finance unemployment benefits and excess government income is
} 
building, constructing houses and providing the necessary infrastructure are time-consuming activities. Moreover, regulations regarding the type and location of housing, as well as the involvement of municipalities and local communities, are likely to delay construction substantially. Once built, the constructs tend to remain in place for decades, or even centuries. Glaeser and Gyourko (2005) present evidence for the US that downward adjustment of the housing stock is even more inelastic than supply of new houses because of durability, implying that urban decline takes much longer than urban growth.

Let us consider a two region model again, where markets are assumed to be in equilibrium. Suppose that one of the regions is hit by an adverse labour demand shock. In this region, wages will go down, unemployment will rise, and labour will migrate to the other region. Durability of housing in the region that experienced the adverse shock implies that supply does not adjust to decreased demand, and house prices go down. Moreover, as supply of housing in the other region is rigid, house prices will go up there in the short run. ${ }^{13}$ Rigidities in housing markets thus create a short-run compensating differential that exceeds compensation in a long-run equilibrium, sustaining regional unemployment differentials out of equilibrium.

Inelastic supply and durability of housing affect aggregate unemployment as well as regional unemployment differentials, because labour mobility would reduce any spatial mismatch of labour supply and demand. Evidence is provided by Bover et al. (1989), who analyse aggregate time series of wages and unemployment in the UK. For both variables, they find an upward effect of regional cost-of-living differentials and of housing market institutions that hamper mobility.

\section{$4 \quad$ Empirical analysis}

Section 2 demonstrates that a plausible set of assumptions may generate equilibrium regional unemployment differentials and compensation in housing markets, but we consider the derived model too stylized for a direct confrontation with the data. In particular, wages are unlikely to be fully fixed by centralized wage bargaining, and there may be compensation in amenity differentials. Therefore, we employ a more general framework for estimation of the

redistributed through lump sum transfers. Although closing the model in this way would make the analytical solution more cumbersome, the qualitative properties of the model would not be affected.

${ }^{13}$ Glaeser et al. (2005) show for US metropolitan areas that positive demand shocks translate into either high house prices and wages or population growth, depending on the rigidity of housing supply. They find a 
compensating differential. Maintaining the assumption that equilibrium is achieved through worker mobility, it is implied that (expected) utility in each region is the same. In the presence of wage and amenity differentials, this no-arbitrage condition (Glaeser and Gyourko, 2005) can be written in the following manner:

housing costs $=f(\underset{+}{\text { wages, }}, \underset{+}{+})$

Equation 5 states that housing costs are higher in locations that offer higher wages, lower unemployment rates and more valuable amenities. We may interpret it as a hedonic model for land rents, fitting the framework that was essentially set out by Rosen (1979) and Roback (1982). ${ }^{14}$ The coefficient for unemployment reflects the compensating differential in housing markets that theory predicts. ${ }^{15}$ It should be noted that it does not have a causal interpretation, because house prices, wages and unemployment are simultaneously determined in a general equilibrium. This no-arbitrage condition underpins our empirical specifications, which are estimated on city-level data in Section 4.1 and on housing demand survey data in Section 4.2. ${ }^{16}$

\subsection{European Urban Audit data}

In the Urban Audit (European Commission, 2004), unemployment and average house price per square meter are observed for 113 cities in 9 different countries, in the period 1999 2003. ${ }^{17}$ Appendix 1 contains a table with all the observations. Although our theoretical analysis was primarily at the level of regions, an empirical analysis of cities has the advantage

significant impact of local regulation on house prices and wages. In Europe, where land use controls are stronger in most countries, these effects are expected to be stronger.

${ }^{14}$ Blomquist et al. (1988) and Gyourko and Tracy $(1989,1991)$ and Glaeser and Gyourko (2005) are studies in the same tradition.

${ }^{15}$ In the theoretical analysis, we have assumed that workers choose a region of residence for their life time. Forward looking behaviour implies a relationship between house prices and (appropriately discounted) future regional unemployment rates or, loosely speaking, the structural unemployment rate. In the empirical analysis, we include the current unemployment rate, which can be regarded as a reasonable approximation of the structural rate in a cross-sectional analysis. However, measurement error implies that our estimates of compensation for structural unemployment are conservative.

${ }^{16}$ The collection of regional house price data for different countries in Europe, let alone micro economic data that allow controlling for housing attributes, has turned out to be a difficult task. Given the relevance of the subject for policy, more effort in the collection of such data by national and international organizations would be most welcome in our view.

17 This dataset is collected by Eurostat, and it contains information on cities in EU member states. Themes covered range from demography and socio-economic aspects to environment. Therefore, the choice for covariates reflecting amenity differentials is relatively broad. The data being presented at three different spatial 
that these are more homogeneous than regions. Moreover, intercity commuting is likely to be much smaller than interregional commuting. ${ }^{18}$ Table 1 shows bivariate relationships between house prices and unemployment rates, both in logarithms, for each country separately.

This analysis provides preliminary evidence of compensation in house prices, indicating a negative relationship with unemployment for each country. For 5 out of 9 countries, including the countries for which we have the most observations, the estimated elasticity is between -0.4 and -0.6. Furthermore, an elasticity in this range would not be statistically rejected at the 10 percent level for any of the other countries. ${ }^{19}$ The relationship seems sufficiently homogeneous over countries to justify pooling of the data. In a regression of house prices on unemployment and country dummies, shown in the first column of Table 2 , we find an elasticity of -0.48 with a standard error of 0.05 . House prices are 5 percent lower on average in cities where unemployment is 10 percent up, which is a sizeable effect.

Table 1: Bivariate regressions of house prices on unemployment

\begin{tabular}{l|cccc}
\hline Country & coefficient & std. error & $R^{2}$ & Nof obs. \\
\hline Denmark & -1.548 & 0.703 & 0.708 & 4 \\
Finland & -0.418 & 0.073 & 0.942 & 4 \\
Czech republic & -0.942 & 0.157 & 0.923 & 5 \\
Sweden & -0.128 & 0.394 & 0.034 & 5 \\
The Netherlands & -0.130 & 0.172 & 0.125 & 6 \\
France & -0.443 & 0.222 & 0.285 & 12 \\
Spain & -0.536 & 0.284 & 0.182 & 18 \\
UK & -0.436 & 0.138 & 0.311 & 24 \\
Germany & -0.532 & 0.058 & 0.714 & 35 \\
\hline
\end{tabular}

Note: average house price per square meter and unemployment are in logarithms. Data points are so-called core cities as defined in European Commission (2004). Countries are put in order of the number of cities observed. The raw data are shown in the Appendix 1.

The no-arbitrage condition (5) states that the estimated relationship between house prices and unemployment can be interpreted as a compensating differential, once we have controlled for wage and amenity differentials. The wage is not observed in the Urban Audit, so we include median household income in a multivariate regression instead. Amenities are measured through population density, temperature, the average temperature of the warmest

levels, we consider the core city level, which is delineated on the basis of administrative boundaries. We leave Estonia out of our sample, since we have only 2 observations for this country.

${ }^{18}$ Commuting between regions weakens the negative relationship between unemployment and house prices, as workers are able to enjoy cheaper housing in one region and more favourable labour market conditions in another region.

19 The precision of the estimate and the share of variation accounted for varies wildly between countries. The standard errors for Germany and Finland are remarkably small and the $\mathrm{R}^{2}$ statistics are large, but in Denmark, 
month, crime, the number of recorded crimes per 1,000 residents and tourism, the number of tourist overnight stays in registered accommodation per year per resident. Population density may be regarded as an amenity if people value short-distance social interactions. More importantly, we include this variable as it is likely to correlate with unobserved amenities, such as a wider choice of theatres, bars and so on. Similarly, tourism is likely to be correlated with unobserved amenities.

Table 2: Estimation of the no-arbitrage equation on average city house prices

\begin{tabular}{|c|c|c|c|c|c|c|}
\hline \multirow[t]{2}{*}{ Variable } & \multicolumn{2}{|c|}{ Model 1} & \multicolumn{2}{|c|}{ Model 2} & \multicolumn{2}{|c|}{ Model 3} \\
\hline & coefficient & std. error & coefficient & std. error & coefficient & std. error \\
\hline unemployment & -0.484 & 0.052 & -0.353 & 0.071 & -0.247 & 0.053 \\
\hline income & & & 0.626 & 0.192 & 0.913 & 0.176 \\
\hline pop. density & & & 0.120 & 0.011 & 0.122 & 0.006 \\
\hline temperature & & & -0.012 & 0.038 & -0.017 & 0.031 \\
\hline crime & & & 0.046 & 0.043 & -0.068 & 0.048 \\
\hline tourism & & & 0.072 & 0.020 & 0.074 & 0.013 \\
\hline Czech republic & -0.883 & 0.008 & -0.783 & 0.037 & & \\
\hline Germany & & & - referen & country - & & \\
\hline Denmark & -0.741 & 0.025 & -0.671 & 0.050 & & \\
\hline Spain & -0.302 & 0.025 & -0.054 & 0.080 & -0.140 & 0.076 \\
\hline Finland & -0.172 & 0.020 & -0.477 & 0.081 & & \\
\hline France & -0.322 & 0.020 & -0.207 & 0.027 & -0.204 & 0.034 \\
\hline The Netherlands & -0.586 & 0.031 & -0.739 & 0.040 & -0.709 & 0.050 \\
\hline Sweden & -0.659 & 0.020 & -0.661 & 0.049 & & \\
\hline UK & -0.500 & 0.015 & -0.375 & 0.032 & & \\
\hline constant & 8.643 & 0.110 & 1.115 & 1.950 & -1.381 & 1.653 \\
\hline $\mathrm{R}^{2}$ & 0.6 & & & & & \\
\hline N. of obs. & 1 & & & & & \\
\hline
\end{tabular}

Note: average house price per square meter is the dependent variable, all variables are in logarithms. In Model 2 , missing values of covariates have been substituted with country means, or sample means if there were less than two observations for a country. In Model 3, there is no substitution of missings and observations for the Czech republic, Denmark, Estonia, Finland, Sweden and the UK have to be excluded. Reported standard errors are robust to heteroskedasticity and correlation within countries. For details on the variables used, see European Commission (2004).

Table 2 presents estimates of house prices on these variables, all taken in logarithms. Next to the regression without controls that we discussed earlier, two other specifications are presented, because the control variables contain a lot of missing observations. In Model 2, missings are substituted with country means, or sample means if there were less than two observations for a country. Model 3 is estimated on the sample of cities for which we observe all controls. For both specifications, statistically significant relationships between house 
prices and unemployment are reported, although controlling for income and amenity differentials reduces the estimate somewhat. Furthermore, the difference between the Model 2 and Model 3 estimates indicates some heterogeneity between countries after including controls in the model, in spite of our findings in Table 1.

Estimated effects of the control variables are consistent with the no-arbitrage interpretation of Equation 5, as housing is more expensive in locations that offer higher incomes or a more attractive set of amenities. The elasticity to household income is close to unity. Of the variables that measure or proxy amenity differentials, only population density and tourism appear to have statistically significant effects. Notably, temperature does not appear to play any role, although US studies tend to find large effects of climate variables (cf. Blomquist et al., 1988). ${ }^{20}$ As consumer amenities are more likely to capitalize in land than in labour markets, this suggests that amenity models, such as estimated for the US by Marston (1985), can not account for within-country regional unemployment differentials in Europe. ${ }^{21}$

\subsection{Evidence from a housing demand survey}

Estimates of compensating differentials in housing markets on aggregate data may be biased, because heterogeneity of the housing stock is ignored. Houses in low-unemployment regions may be more expensive, because the average quality is higher. Presumably, this bias is limited, because house prices in our city-level analysis are scaled to area, and because we control for income and amenity differentials. However, the point is further examined here, in an analysis of quality-controlled house prices. Since these prices may be regarded as land rents, the interpretation of Equation 5 as a hedonic land rent model is enhanced.

Land rent differentials are estimated by regressing house prices on characteristics and region dummies. We perform this hedonic house price analysis on Dutch housing demand surveys (WBO's) for the years 1985 and 2002, which have a sample size of roughly 100,000 households each. The broad range of housing variables includes space-related attributes such the type of house, the number of rooms and availability of a garden, as well as other attributes such as year of construction and availability of central heating. In addition, our dataset contains labour market related household characteristics, such as age and educational

\footnotetext{
${ }^{20}$ We have experimented with other climate variables but all appeared to be statistically insignificant.

${ }^{21}$ Indeed, in a regression of unemployment on amenity variables, we found no significant effect of temperature. Moreover, tourism had a negative effect and unemployment and crime appeared to be positively correlated, although the amenity model of unemployment would predict reverse signs.
} 
attainment of some members as well as wages and household income. ${ }^{22}$ The regional level considered is the European NUTS3 level, which consists of 40 so-called COROP regions. ${ }^{23}$ Results for the hedonic house price model are shown in Appendix 2. Bivariate relationships between unemployment and both house prices and land rents, controlled for period-specific heterogeneity, are presented in Table 3.

Table 3: Bivariate regressions of house prices and land rents on unemployment

\begin{tabular}{l|cccc}
\hline Dependent variable & coefficient & std. error & $R^{2}$ & Nof obs. \\
\hline Average regional house price & -0.244 & 0.060 & 0.283 & 80 \\
Land rent from hedonic model & -0.336 & 0.072 & 0.302 & 80 \\
\hline
\end{tabular}

Note: all variables are in logarithms. Land rents are obtained by estimating a hedonic house price model that includes region dummies, results are shown in Appendix 2. Time dummies are included in these bivariate models, and standard errors are robust to autocorrelation and heteroskedasticity between regions.

Consistent with our findings for city-level data, Table 3 indicates that both average house prices and land rents are about 3 percent lower in regions where unemployment is 10 percent up. It suggests that ignoring heterogeneity of the housing stock leads to underestimation of the relationship between house prices and unemployment, although the difference is not statistically significant.

Table 4: Estimation of the no-arbitrage equation on regional house prices and land rents

\begin{tabular}{l|cccc}
\hline Variable & \multicolumn{2}{|c}{ Model 1 (house prices) } & \multicolumn{2}{c}{ Model 2 (land rents) } \\
& coefficient & std. error & coefficient & std. error \\
\hline Unemployment & -0.156 & 0.068 & -0.158 & 0.058 \\
Regional component wages & 0.629 & 0.625 & 0.889 & 0.522 \\
Population density & 0.059 & 0.033 & 0.148 & 0.027 \\
\hline $\mathrm{R}^{2}$ & \multicolumn{2}{|c}{0.419} & \multicolumn{3}{c}{0.742} \\
Number of observations & \multicolumn{2}{|c}{80} & \multicolumn{2}{c}{80} \\
\hline
\end{tabular}

Note: all variables are in logarithms. The regional component of wages is obtained by regressing male hourly wages on age and educational attainment (both in 5 classes) as well as region dummies for each period. Coefficients of time dummies are included in the regressions, but not reported in the table. Standard errors are robust to autocorrelation and heteroskedasticity between regions.

Again, in order to interpret the relationship between land rents and unemployment as a compensating differential, we include regional wage and amenity differentials in our analysis.

\footnotetext{
${ }^{22}$ We supplement these data with regional unemployment data taken from two sources. Unemployment in 2002 is derived from the labour force survey (EBB) from Statistics Netherlands, and for 1985 we use registered unemployment (Sociaal-economische Maandstatistiek, 1985). From a 1985 labour force survey, we have regional unemployment data for a higher level of spatial aggregation. At that level, it correlates almost perfectly with the registered unemployment data. Also, we use population density from Statistics Netherlands.

${ }^{23}$ This dataset is less suitable for estimation of the relationship between house prices and unemployment at the city level. Ignoring interregional commuting, we would expect to find the same relationship at the regional as at
} 
Our dataset allows to control for the regional component to wages rather than average household income, which is consistent with an interpretation of the regression model as a noarbitrage condition. It is obtained by regressing wages of full-time working males on age, educational attainment and period-specific region dummies. Amenity differentials are measured by population density. Furthermore, we include period dummies. Table 4 shows estimates where the dependent variable is either regional average house prices (Model 1) or land rents (Model 2).

In regressions that include wage and amenity differentials, both house prices and land rents appear to be almost 2 percent lower in regions where unemployment is 10 percent up. ${ }^{24}$ Therefore, controlling for heterogeneity of the housing stock does not seem to affect our estimate of the compensating differential. ${ }^{25}$ Furthermore, land is more expensive in locations that offer higher wages or more attractive amenities, as reflected in a higher population density. The coefficients are consistent with our findings for European cities in Table 2. Note that these effects are not statistically significant when we regard average house prices instead of land rents, and they account for a much smaller share of the variance. ${ }^{26}$

The pattern of observed land prices, unemployment and wages in the Netherlands seems consistent with the core-periphery model of section 2 , with a core consisting of the densely populated regions in the west of the country (the Randstad area). Estimation of a standard wage curve equation on our data yields an elasticity of -0.06 , which is significantly smaller than the -0.10 coefficient of Blanchflower and Oswald (1994). Hence, rigidities due to centralized wage bargaining seem to play a role. Higher wages in the Randstad plausibly reflect a productivity advantage due to economies of agglomeration. As predicted by our model, land prices in this area are above, and unemployment is below the national average.

the city level, since micro data allow to control for urban-rural heterogeneity of the housing stock to a large extent.

${ }^{24}$ Consistent with our findings in Table 1, the estimated compensating differential is somewhat smaller in the Netherlands than in other European countries. Commuting between the COROP regions, which averages about 20 percent of the working labour force, may account for this difference. We have included a spatial lag of unemployment in the regression (the average of unemployment in neighbouring regions), but this variable was not statistically significant.

${ }^{25}$ Replacing the regional component to wages by average household income, we obtained a similar result.

${ }^{26}$ Estimates of the compensating differential for 1985 and 2002 separately do not deviate from the estimates in Table 4 in a statistically significant way. Observing unemployment and house prices for two periods, it is possible to include regional fixed effects in the hedonic land rent model. However, it is the structural component to regional unemployment differentials that is compensated in housing markets, and changes of unemployment over time are likely to capture this component less well than levels do. Moreover, the variation over time is too limited to enable identification. The correlation coefficient of the logarithm of unemployment in 1985 and 2002 is 0.50 , for wages it is 0.70 and for household income it is 0.62 . Nevertheless, changes of unemployment over the period 1985 - 2002 correlate negatively to changes in land prices, although this relationship is not statistically significant. 
An important point we take from our analysis of housing demand survey data is that analyses using aggregate house price data are unlikely to overestimate the compensating differential. This indicates that conclusions from our analysis of the Urban Audit data, which draw on variation in house prices and unemployment rates for several countries, are not critically flawed because of omission of housing quality characteristics.

\section{$5 \quad$ Conclusions and policy implications}

This paper has provided empirical evidence for compensation of regional unemployment differentials in housing markets. Employing an extensive dataset on European cities, an elasticity ranging from -0.6 to -0.4 could not be rejected for any of the 9 countries observed. Including city-level income and amenity variables in a regression that was interpreted as a noarbitrage condition, a somewhat smaller compensating differential was found. An analysis of housing demand surveys for the Netherlands indicated that these findings are robust to omission of house attributes.

Do these estimates imply full compensation of regional unemployment? We address this question by comparing the income effect of an increase in regional unemployment to the income effect of an associated decrease in house prices. ${ }^{27}$ Suppose that workers spend about a third of their income on housing, and that benefits amount to 70 percent of wages. If there is no wage curve, then with an elasticity of -0.3 , compensation in house prices exceeds the income loss due to increased probability of unemployment by far. ${ }^{28}$ However, the two effects come remarkably close to cancelling out when we assume a wage curve elasticity of $-0.10{ }^{29}$ The sizable compensating differential indicated by our empirical results thus strongly suggests that high regional unemployment rates proxy less favourable labour market conditions, which may also result in lower wages. ${ }^{30}$ Hence, we regard it as indirect evidence of the wage curve.

\footnotetext{
${ }^{27}$ This is obviously a rather rough evaluation of compensation, which ignores any substitution effects, as well as compensating differentials in other markets, in particular for nontradables, that are likely to correlate to the price differential in housing markets. Heterogeneity of the labour force is not accounted for either. Compensation in housing markets may not accrue to the unemployed in particular, nor to groups that are most vulnerable to unemployment. On the contrary, as these groups are likely to be overrepresented in the highly regulated rental market, they may find it more difficult to benefit from lower house prices. We do not consider the rental market explicitly in this paper, but further research on this topic would be most welcome in our view.

${ }^{28}$ If unemployment is 5 percent, then the income effect due to lower house prices is roughly about a factor 10 higher than the expected income loss due an to increased probability of unemployment.

${ }^{29}$ Note that for the Netherlands, we found a smaller elasticity of both house prices and wages to regional unemployment. Therefore, the two income effects come close to cancelling out for this country as well.

${ }^{30}$ It is common practice to regard the unemployment rate as a macro-economic indicator. In a similar vein, the regional unemployment rate indicates regional economic conditions. It may be correlated with wages, but also with the quality of matches and other labour market variables. The evidence thus suggests that housing markets
} 
Existence of a compensating differential in housing markets has a number of implications for policy. Currently, the European Union and many of its member countries spend billions of euros on regional support programs, which are motivated at least partly by equity considerations. Our evidence suggests that equity may be less of an issue, as people in backward regions receive compensation already. Expected utility may therefore be the same in each region, and if so, regional support programs should be justified rather on efficiency grounds. Our analysis may also help to understand why regional unemployment differentials have remained so persistent, in spite of these generous support programs.

Compensation in housing markets has implications for labour market policies as well. In a theoretical model, we have shown that regional unemployment differentials may result from centralized wage bargaining. Therefore, the recommendation of $\operatorname{OECD}(2000,2005)$ and European Commission (2003) to relax the regional wage rigidities associated with these institutions applies in the framework of our model. Moreover, in most European countries unemployment benefit levels are also set at the national level. Compensation then implies a regional differential in real benefit levels. The desirability of such a differential is questionable from the perspective of equity. Also, it may reduce the incentive to job search for people in high-unemployment regions more than in other regions. Hence, there would be a case for adjustment of unemployment benefit levels to regional cost-of-living differentials.

A third area of policy we touch upon refers to housing markets and spatial planning. As we have argued in section 3, housing markets may play a major role in regional adjustment processes, because of inelastic supply and durability of housing. These properties of the good are not necessarily related to regulations. However, in many European countries, governments, municipalities and other local bodies have a major say in what type of housing should be constructed and where it should be built. This public involvement is generally thought to delay and restrict housing supply, and therefore increases the compensating differential. In turn, regional adjustment of labour supply and clearing of aggregate labour markets is hampered (cf. Bover et al., 1989). Furthermore, the supply of land for habitation or production is restricted by spatial planning and land use controls. Therefore, these policies may also increase regional differentials in house prices and unemployment in equilibrium.

compensate for regional labour market conditions, rather than for the loss in expected income due to unemployment only. As wages and unemployment do not correlate perfectly, both are informative on these conditions. Consequently, the positive relationship between house prices and the regional component to wages, or average household income, may also be interpreted as compensation for regional labour market conditions. 


\section{References}

Baltagi, B. H. and Blien, U. (1998). "The German wage curve: evidence from the IAB employment sample." Economics Letters, 61(2), 135-142.

Blackaby, D. and Manning, D. N. (1992). "Regional earnings and unemployment - a simultaneous approach." Oxford Bulletin of Economics and Statistics, 54, 481-501.

Blanchflower, D. G. and Oswald, A. J. (1994). The wage curve, MIT, Cambridge,MA.

Blomquist, G., Berger, M. and Hoehn J. (1988). "New estimates of quality of life in urban areas." American Economic Review, 78, 89-107.

Bover, O., Muellbauer, J., and Murphy, A. (1989). "Housing, wages and UK labour markets." Oxford Bulletin of Economics and Statistics, 51(2), 97-136.

Brueckner, J. F. and Zenou, Y. (1999). "Harris-Todaro models with a land market." Journal of Urban Economics, 29, 317-339.

Cameron, G. and Muellbauer, J. (1998). "The housing market and regional commuting and migration choices." Scottish Journal of Political Economy, 45, 420-446.

Cameron, G. and Muellbauer, J. (2001). "Earnings, unemployment and housing in Britain." Journal of Applied Econometrics, 16(3), 203-220.

Card, D. (1995). "The wage curve: A review." Journal of Economic Literature, 33(2), 285299.

Carlson, F. (2000). "Testing equilibrium models of regional disparities." Scottish Journal of Political Economy, 47, 1-24.

European Commission (2003). "Employment in Europe 2003." Luxemburg: Office for Official Publications of the European Commision.

European Commission (2004). "Urban Audit: methodological handbook." Luxemburg: Office for Official Publications of the European Commision.

Faini, R. (1999). "Trade unions and regional development." European Economic Review, 43, 457-474.

Fujita, M. (1989). Urban economic theory, Cambridge University Press, Cambridge, UK.

Glaeser, E. L. and Gyourko, J. (2005). "Urban decline and durable housing." Journal of Political Economy, 113(2), 345-375.

Glaeser, E. L., Gyourko, J., and Saks, R. E. (2005). "Urban growth and housing supply." National Bureau of Economic Research.

Groot, W., Mekkelholt, E., and Oosterbeek, H. (1992). "Further evidence on the wage curve." Economics Letters, 38, 355-359. 
Gyourko, J. and Tracy, J. (1989). "The importance of local fiscal conditions in analysing local labor markets." Journal of Political Economy, 97, 1208-31.

Gyourko, J. and Tracy, J. (1991). "The structure of local public finance and the quality of life." Journal of Political Economy, 99, 774-806.

Hall, R. E. (1970). "Why is the unemployment rate so high at full employment?" Brookings Papers on Economic Activity, 1970(3), 369-410.

Hall, R. E. (1972). "Turnover in the labor force." Brookings Papers on Economic Activity, 72(3), 709-756.

Harris, J. and Todaro, M. (1970). "Migration, unemployment and development: a two-sector analysis." American Economic Review, 60, 126-142.

Helpman, E. (1998). "The size of regions." Topics in public economics. Theoretical and applied analysis, D. Pines, E. Sadka, and I. Zilcha, eds., Cambridge University Press, Cambridge, 33-54.

Hughes, G. and McCormick, B. (1987). "Housing markets, unemployment and labour market flexibility in the UK." European Economic Review, 31(3), 615-641.

Jackman, R. and Savouri, S. (1992). "Regional migration in Britain: an analysis of gross flows using NHS Central Register data." Economic Journal, 102(415), 1433-1450.

Marston, S. (1985). "Two views of the geographic distribution of unemployment." Quarterly Journal of Economics, 100, 57-79.

Minford, P., Peel, M., and Ashton, P. (1987). The housing morass, Institute of Economic Affairs, London.

OECD (2000). "Employment Outlook 2000 Chapter 2: Disparities in regional labour markets." OECD, Paris.

OECD (2004). "Employment Outlook 2004 Chapter 3: Wage-setting institutions and outcomes." OECD, Paris.

OECD (2005). "Employment Outlook 2005 Chapter 2: How persistent are regional disparities in employment? The role of geographic mobility" OECD, Paris.

Oswald, A.J. (1999). "The housing market and Europe's unemployment: a non-technical paper." University of Warwick, United Kingdom.

Ottaviano, G., Tabuchi, T., and Thisse, J. F. (2002). "Agglomeration and trade revisited." International Economic Review, 43(2), 409-435.

Overman, H. G. and Puga, D. (2002). "Unemployment clusters across Europe's regions and countries." Economic Policy, 34, 115-147. 
Roback, J. (1982). "Wages, Rents and the Quality of Life." Journal of Political Economy, 90(6), 1257-1278.

Rosen, S. (1979). "Wage-based indexes of urban quality of life." Current issues in urban economics, P. Mieszkowksi and M. Straszheim, eds., John Hopkins University Press, Baltimore.

Smith, L. B., Rosen, K. T., and Fallis, G. (1988). "Recent developments in economic models of housing markets." Journal of Economic Literature, 26, 29-64.

Smith, T. E. and Zenou, Y. (2003). "Spatial mismatch, search effort and urban spatial structure." Journal of Urban Economics, 54, 129-156.

Sociaal-economische maandstatistiek (1985). “Tabel 1.5.8: Bij de arbeidsbureaus geregistreerde werklozen naar Corop-regio en geslacht, eind juni 1985”, 2(8), 28.

Tabuchi, T. (1998). "Agglomeration and dispersion: a synthesis of Alonso and Krugman." Journal of Urban Economics, 44, 333-351.

Zenou, Y. and Smith, T. E. (1995). "Efficiency wages, involuntary unemployment and urban spatial structure." Journal of Urban Economics, 25, 547-573. 
Appendix 1: City-level house prices and unemployment rates

\begin{tabular}{|c|c|c|c|c|c|c|c|c|}
\hline city & $\begin{array}{l}\text { house } \\
\text { price }\end{array}$ & unemp. & city & $\begin{array}{l}\text { house } \\
\text { price }\end{array}$ & unemp. & city & $\begin{array}{l}\text { house } \\
\text { price }\end{array}$ & unemp. \\
\hline Czech republic & & & Erfurt & 1432 & 15.1 & Rotterdam & 1423 & 5.9 \\
\hline Praha & 1563 & 5.4 & Augsburg & 2270 & 5.5 & Utrecht & 1364 & 3.0 \\
\hline Brno & 781 & 9.1 & Bonn & 2127 & 4.5 & Groningen & 1384 & 6.4 \\
\hline Ostrava & 469 & 17.3 & Karlsruhe & 2454 & 5.3 & Arnhem & 1410 & 5.9 \\
\hline Plzen & 781 & 8.1 & Mönchengladbach & 2250 & 7.2 & Finland & & \\
\hline Usti nad Labem & 625 & 13.5 & Mainz & 2618 & 5.2 & Helsinki & 1943 & 5.8 \\
\hline Denmark & & & Spain & & & Tampere & 1307 & 16.0 \\
\hline København & 1546 & 4.5 & Madrid & 1855 & 12.4 & Turku & 1316 & 16.3 \\
\hline Aarhus & 1321 & 5.2 & Barcelona & 2500 & 10.8 & Oulu & 1181 & 15.9 \\
\hline Odense & 1039 & 5.2 & Valencia & 874 & 14.2 & Sweden & & \\
\hline Aalborg & 1052 & 5.8 & Sevilla & 1028 & 22.8 & Stockholm & 2064 & 3.3 \\
\hline Germany & & & Zaragoza & 1102 & 11.8 & Göteborg & 1409 & 5.6 \\
\hline Berlin & 1759 & 14.9 & Málaga & 965 & 21.0 & Malmö & 1468 & 9.1 \\
\hline Hamburg & 2250 & 7.6 & Murcia & 698 & 11.5 & Jönköping & 791 & 3.4 \\
\hline München & 3784 & 3.6 & Las Palmas & 1222 & 19.9 & Umeå & 935 & 11.0 \\
\hline Köln & 2454 & 7.3 & Valladolid & 1172 & 14.6 & $\begin{array}{l}\text { United } \\
\text { Kingdom }\end{array}$ & & \\
\hline $\begin{array}{l}\text { Frankfurt am } \\
\text { Main }\end{array}$ & 3150 & 5.4 & Palma di Mallorca & 1381 & 12.0 & London & 2904 & 6.5 \\
\hline Essen & 2495 & 7.7 & $\begin{array}{l}\text { Santiago de } \\
\text { Compostela }\end{array}$ & 1055 & 12.2 & Birmingham & 1318 & 9.5 \\
\hline Leipzig & 1473 & 17.4 & Vitoria/Gasteiz & 1744 & 9.9 & Leeds & 1336 & 5.1 \\
\hline Dresden & 1677 & 14.7 & Oviedo & 1180 & 14.1 & Glasgow & 1321 & 10.8 \\
\hline Dortmund & 2413 & 9.6 & Pamplona/Iruňa & 1655 & 10.7 & Bradford & 1042 & 6.9 \\
\hline Düsseldorf & 2577 & 6.3 & Santander & 1319 & 15.7 & Liverpool & 992 & 11.1 \\
\hline Bremen & 1452 & 8.3 & Toledo & 889 & 10.8 & Edinburgh & 2014 & 5.2 \\
\hline Hannover & 1595 & 9.4 & Badajoz & 661 & 20.9 & Manchester & 1307 & 9.0 \\
\hline Nürnberg & 2413 & 7.6 & Logroňo & 1180 & 10.6 & Cardiff & 1489 & 4.9 \\
\hline Bochum & 2372 & 7.8 & France & & & Sheffield & 1136 & 6.7 \\
\hline Wuppertal & 2004 & 6.5 & Lyon & 1400 & 11.5 & Bristol & 1533 & 4.6 \\
\hline Bielefeld & 1841 & 7.8 & Bordeaux & 1200 & 14.3 & Belfast & 1361 & 9.6 \\
\hline $\begin{array}{l}\text { Halle an der } \\
\text { Saale }\end{array}$ & 1104 & 20.8 & Nantes & 1200 & 13.2 & $\begin{array}{l}\text { Newcastle } \\
\text { upon Tyne }\end{array}$ & 1189 & 8.0 \\
\hline Magdeburg & 1432 & 19.0 & Lille & 1200 & 14.4 & Leicester & 1084 & 7.9 \\
\hline Wiesbaden & 3477 & 6.0 & Saint-Etienne & 1000 & 13.5 & Derry & 951 & 12.0 \\
\hline Göttingen & 1800 & 10.0 & Le Havre & 1000 & 17.1 & Aberdeen & 1408 & 5.0 \\
\hline $\begin{array}{l}\text { Mülheim } \\
\text { a.d.Ruhr }\end{array}$ & 1963 & 6.1 & Rennes & 1400 & 9.0 & Cambridge & 2536 & 3.8 \\
\hline Moers & 2045 & 6.6 & Nancy & 1000 & 11.1 & Exeter & 1553 & 3.9 \\
\hline Darmstadt & 2556 & 5.3 & Orléans & 1400 & 8.7 & Lincoln & 1016 & 6.4 \\
\hline Trier & 1841 & 7.6 & Dijon & 1400 & 10.7 & Gravesham & 1937 & 5.2 \\
\hline $\begin{array}{l}\text { Freiburg im } \\
\text { Breisgau }\end{array}$ & 2700 & 6.0 & Grenoble & 1600 & 13.2 & Stevenage & 1762 & 4.0 \\
\hline Regensburg & 2104 & 6.3 & Ajaccio & 1000 & 14.2 & Wrexham & 1179 & 5.1 \\
\hline Frankfurt (Oder) & 1340 & 18.9 & The Netherlands & & & Portsmouth & 1571 & 4.6 \\
\hline Weimar & 1432 & 14.7 & s' Gravenhage & 1714 & 3.4 & Worcester & 1549 & 3.8 \\
\hline Schwerin & 1227 & 15.8 & Amsterdam & 1781 & 4.3 & & & \\
\hline
\end{tabular}

Note: these data are obtained from the Urban Audit (European Commission, 2004). The spatial level considered is the core city, which is delineated on the basis of administrative boundaries. House prices refer to the average house price in euros per square meter. These data refer to the period 1999 - 2003 (so not to the same year for each country). 
Appendix 2: Hedonic house price analysis (used to obtain land rents)

\begin{tabular}{|c|c|c|}
\hline Variable & coefficient & standard error \\
\hline \multicolumn{3}{|l|}{ Dwelling type (reference is apartment) } \\
\hline free standing & 0.478 & 0.047 \\
\hline semi-detached (1985) & 0.209 & 0.051 \\
\hline semi-detached (2002) & 0.190 & 0.053 \\
\hline corner house & 0.066 & 0.051 \\
\hline terraced house & -0.018 & 0.051 \\
\hline \multicolumn{3}{|l|}{ Number of rooms (reference is 1) } \\
\hline 2 & 0.070 & 0.089 \\
\hline 3 & 0.233 & 0.092 \\
\hline 4 & 0.358 & 0.092 \\
\hline 5 & 0.446 & 0.091 \\
\hline 6 & 0.546 & 0.089 \\
\hline 7 or more & 0.690 & 0.092 \\
\hline Garden & 0.152 & 0.024 \\
\hline Size living room exceeds $30 \mathrm{~m}^{2}$ & 0.165 & 0.005 \\
\hline Size kitchen exceeds $8 m^{2}$ (1985) & 0.050 & 0.008 \\
\hline Size kitchen exceeds $8 \mathrm{~m}^{2}$ (2002) & 0.104 & 0.006 \\
\hline Central heating (1985) & 0.235 & 0.011 \\
\hline Central heating (2002) & 0.158 & 0.015 \\
\hline Double-glazing in living room & 0.023 & 0.010 \\
\hline Double-glazing in rest of the house (1985) & 0.067 & 0.007 \\
\hline Double-glazing in rest of the house (2002) & 0.037 & 0.008 \\
\hline Balcony (no ground floor apartment) & 0.090 & 0.009 \\
\hline Elevator (no ground floor apartment) & 0.103 & 0.054 \\
\hline \multicolumn{3}{|c|}{ Period of construction (reference is before 1945) } \\
\hline $1945-1959$ & -0.046 & 0.011 \\
\hline $1960-1969(1985)$ & 0.030 & 0.011 \\
\hline $1960-1969(2002)$ & -0.104 & 0.017 \\
\hline $1970-1979(1985)$ & 0.087 & 0.011 \\
\hline $1970-1979(2002)$ & -0.049 & 0.015 \\
\hline after $1979(1985)$ & 0.094 & 0.018 \\
\hline $1980-1989(2002)$ & -0.031 & 0.014 \\
\hline after 1989 (2002) & 0.077 & 0.015 \\
\hline Dummy 2002 & 1.399 & 0.025 \\
\hline Constant & 10.061 & 0.110 \\
\hline Region dummies 1985 (40) & \multicolumn{2}{|c|}{ included } \\
\hline Region dummies 2002 (40) & \multicolumn{2}{|c|}{ included } \\
\hline$R^{2}$ & \multicolumn{2}{|c|}{0.794} \\
\hline Number of observations & \multicolumn{2}{|c|}{49,459} \\
\hline
\end{tabular}

Note: hedonic regression of house prices in logarithms on characteristics and period-specific region dummies, estimated on Dutch housing demand survey data (WBO) for 1985 and 2002. We have estimated two specifications of this model. In one specification, all coefficients were period-specific. In the second specification, which is reported here, only statistically significant variation of coefficients over time was allowed for. For these variables, the year between brackets indicate the period to which the effect refers. Reported standard errors are robust to autocorrelation and heteroskedasticity at the regional level. Coefficients for periodspecific dummies are used as estimates of regional land rent differentials in the paper. 